\title{
Learning Skills Levels in Reading, Writing, Listening, Memorizing, Test Taking and Using Technology of Counseling Students in Indonesia
}

\author{
Neviyarni Neviyarni ${ }^{a}$, Netrawati Netrawati ${ }^{\text {b }}$ Romi Fajar Tanjung ${ }^{c *}$, Reizki Maharanid ${ }^{\mathrm{d}}$, Ria Hayati ${ }^{\mathrm{e}}$ \\ bcde State University of Padang, Faculty of Education, Padang, Indonesia
}

\begin{abstract}
The majority of students' learning skills are at the medium level. Learning skills is one of the many skills that need to be trained and mastered by students in order to be able to have satisfactory academic results. One factor that influences learning skills is learning attitude and behavior. This study aims to examine the first year Counseling students' learning skills condition in State University of Padang. Learning skills explored in this study are skills in reading, writing, memorizing, test taking and using technology. The population of the study is all first-year students majoring in Counseling. The sampling technique is a random sampling. The study sample is 44 students. Data were analyzed using a descriptive analysis. The results show that the majority of students' learning skills is below high category, which is $88,63 \%$. Most of the students' learning skills need to be improved in listening, reading and test-taking skills and they have some weaknesses in learning skills in using technology, memorizing and writing.
\end{abstract}

Keywords: Interactive plot viewer providing easy access to the data behind plots. Please prepare a .CSV file with your plot data and test it online here before submitting as supplementary material

\section{Introduction}

Someone who had just enrolled in a university requires self-adjustment to his life because learning process in the university will be very different and demand a strong independence (Hiester, Nordstorm, \& Swenson, 2009). The transition period from middle to tertiary education level is demanding both academically and socially (Gourlay, 2009). Poor transitions when entering college will have a bad impact, such as low academic achievement, and result in dropping out of school (Beaubouef \& Mason, 2005).

In order to have a successful study, students need several special skills. These skills are related to knowledge and must be mastered by the students so that they are ready to follow lectures and pass the first year of college successfully (Conley, 2005). Various forms of learning skills that need to be mastered by students include reading, recording, listening, presenting, making conclusions, time management and making tasks well and concentration (Smith, 2000; Elliot, Kratotchwill, Cook \& Travers, 2000; Pan, 2004; Pepe, 2012).

This study aims to see describe the new Counseling students' learning skills. Learning skills that are measured include reading, recording, listening, auditing, completing academic assignments and using technology to support their academic success.

\footnotetext{
${ }^{*}$ Corresponding Author.

E-mail address: romifajarr@gmail.com (R.F. Tanjung), neviyarni@konselor.org (N. Neviyarni), netrawatiunp07@gmail.com (N. Netrawati).
} 
Students who have just enrolled in a university are required to be able to follow lectures effectively, one of which is by attending a classically scheduled face-to-face activity. They are also obliged to complete all the assignments given by the lecturers. Students in universities always face a variety of specific responsibilities in the academic field (Kreniske, 2017).

Students are also required to be able to deal with demands and pressures such as reading literature, presenting material or submitting lecture assignments on time. However, in reality, many students are late in handing their assignments and they often do the assignments a day before its due date. The attitude or behavior of students postponing the task shows that the student's learning ability is not optimal (Kagan, Cak, Ilhan \& Kandemir, 2010; Shahram \& Vahedi, 2010).

Students need to have the willingness to improve their learning skills because without intrinsic motivation students' learning skills will never improve. When students consider the material as not interesting but are forced to keep listening to the material because they are anxious and afraid of getting low learning outcomes, these kind of students are more likely to be passive and resort to memorizing in learning (Grills, 2017; Thomas \& Gadbois, 2007).

Aside from students' willingness, experts and professional activities are also needed to assist students in increasing their potential. One expert who plays a role in improving students' learning skills is counselor (Isari, Efendi, \& Neviyarni, 2017), in the form of classical guidance services (Fitri, Ifdil, \& Neviyarni, 2016), as well as in groups (Sukmawati, Neviyarni, Syukur , \& Said, 2013). Thus, the role of the counselor also needs to be improved to help improve the skills of students in college.

\section{Method}

This research uses a qualitative method. The population is students majoring in Counseling in 2017, with 44 people as the sample. Data collection techniques used RNF Learning Skills Instrument (Tanjung, Neviyarni, \& Firman, 2017). Instruments validity and reliability were tested using the RASCH Model developed by George Rasch (Sumintono \& Widhiarso, 2014). Items that did not meet the criteria were not used, and the item reliability is 0.93 (Excellent), the person reliability is 0.93 (Excellent), and Cronbach alpha which measures the interaction between respondents and items shows a reliability value of 0.94 (Very Good). Data were analyzed using a quantitative descriptive analysis. After the data were obtained, they were analyzed using theories and results of previous studies to choose and determine the right intervention in improving and optimizing the learning skills of students who have just enrolled in the university.

\section{Result and Discussion}

The results of the study revealed the condition or the level of students' learning skills and explained the students' skills in each aspect, which includes skills in reading, writing, listening, memorizing, test taking and using technology.

\section{Figure 1. Percentage Level of Student Learning Skills}

\section{Percentage Level of Student Learning Skills}

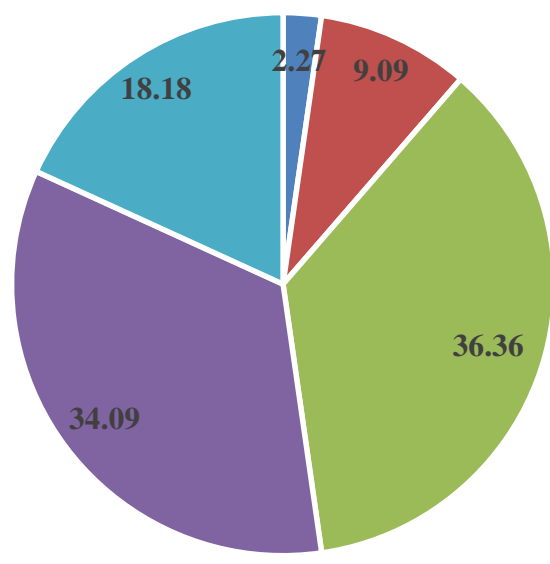

- Very High - High - Medium - Low = Very Low 
Figure 1 shows that most students have the learning skills below the high category (88.63\%), while students in the high category have the percentage of $9.09 \%$, and those in the very high category have the percentage of $2.27 \%$. Thus, students who have optimal learning skills amount to $11.36 \%$ of the total sample.

Based on Figure 2, the results of the study shows that out of the six aspects measured, such as reading, writing, listening, memorizing, taking tests and using technology, most students had weaknesses in listening, followed by reading, and test taking and the last skills are the use of technology, memorizing and writing. The number of students in the high category in listening comprised of 41 people, 34 people in the reading, 32 people in the test-taking, 28 people in using technology, 28 people in memorizing, and 22 people on the writing. Based on the research findings above, it is necessary to do the right intervention to optimize student learning skills, especially in listening, reading and test taking.

Figure 2. Level of Student Learning Skills in Each Aspect

\begin{tabular}{|c|c|c|c|c|c|c|}
\hline \multicolumn{7}{|c|}{ Level of Student Learning Skills in Each Aspect } \\
\hline 20 & & & & & & \\
\hline 15 & & & & & & \\
\hline 10 & 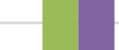 & & & & & \\
\hline 5 & & & & & & \\
\hline 0 & Reading & Writing & Listening & Memory & Taking Test & Use Technology \\
\hline घ Very High & 2 & 5 & 1 & 3 & 5 & 3 \\
\hline a High & 8 & 17 & 2 & 13 & 7 & 13 \\
\hline Medium & 15 & 18 & 12 & 20 & 14 & 15 \\
\hline - Low & 15 & 1 & 20 & 7 & 9 & 11 \\
\hline Very Low & 4 & 3 & 9 & 1 & 9 & 2 \\
\hline
\end{tabular}

\section{Discussion}

Based on research findings, it is concluded that the majority of Counseling students have low and medium learning skills. The percentage of students with medium learning skill is $36,36 \%$, low learning skill is $34,00 \%$, really low learning skill is $18,18 \%$, high learning skill is $9,09 \%$, and really high learning skill is only around $2,27 \%$. As seen from the research findings above, students learning skills need to be improved to maximize the students' potential so that it has a positive impact on students' academic achievement in the future.

In the transition period when a student starts the college life, he/she is required to be more independent and more responsible. Then, the ability to adapt to the college environment and the learning process can be categorized as successful if the student is able to manage his/her time well, and is able to develop skills in the academic and social fields to deal with the existing stressors and challenges (Hiester, Nordstorm \& Swenson, 2009).

Various kinds of learning skills need to be mastered by a student, such as skills in reading, writing, listening, memorizing, time management, taking test, and also one of the most important skills to be mastered by students of 
millennial era, the skill to master the use of technology, which is needed to support a better learning process. Based on the findings, Counseling students have weaknesses in listening, reading, and using technology.

The number of students who are weak in listening skills is 41 people $(93,18 \%)$. Research results recommend that listening skill practice to become an integral part of a university curriculum (Ferrari-Bridgers, Vogel, \& Lynch, 2015). When a person is listening, there are three processes that are happening as well, which include cognitive, behavior and attitude processes that make the listening beneficial to the listener. However, those three processes can be influenced by several factors such as physical, contextual, intellectual ability, psychological traits, attitude or listening style, individual listening behavior, age, and social-cultural factors (Thompson, Leintz, Nevers, \& Witkowski, 2004; Janusik, 2007; Bodie, Worthington, Imhof, \& Cooper, 2008; Bodie, 2013).

Wolvin (2012), who has conducted research in listening for more than two decades, recognize that students received interpersonal benefits, both in education and career levels when they have a good listening skill. Some studies suggest that listening skill is very important for the success of learning (Davis, 2001). An effective listening skill contributes to an individual performance in an organization (Flynn, Välikoski, \& Grau, 2008).

The number of students who has low reading skill is 34 people $(77,27 \%)$. A good reading skill will positively contribute to the students' education and career in the future (Leppanen, Aunola, \& Nurmi, 2005; McGeown, Duncan, Griffiths, \& Stothard, 2014). One program that has succeeded in improving the reading ability for adults, children and dyslexic people is the Reading Acceleration Program (RAP) (Breznitz et al., 2013; Horowitz-Kraus et al., 2014).

A lot of new knowledge can be obtained from reading written information because the written texts do not only contain facts and information, but also ideas, opinions, cultural values and content (Artfelt, \& Dörfler, 2010). In the elementary school, a student who succeeds in reading is a measurement of a significant success of a learning process (Pfost, Hattie, Dörfler, \& Artfelt, 2014). Formal education should have equipped their students with reading skill to help them to find and absorb written information fluently and well, since someone who does not have a basic skill needed to read well will be in risks of becoming a bad reader in the future (Snowling, 2001; Vellutino, Fletcher, Snowling, \& Scanlon, 2004).

The number of students who has low test-taking skill is 32 people $(72,73 \%)$. One example of low ability in test taking is the tendency to put off to start doing and finishing a given academic assignment (Hussain \& Sultan, 2010). An assignment which is not done on time and optimally will have an impact on an individual's psychology, as the self-efficacy becomes lower and academic achievement worse (Kiamarsi \&Abolghasemi, 2014).

The number of students who has a low ability in using technology is 28 people $(63,64 \%)$. In this millennial era, using technology is a very important skill to be mastered by students, because this skill helps in the education process such as in making the presentation more interesting, making data processing easier or helping to find out literature reference.

The number of students who has low memorizing skill is 28 people $(63,64 \%)$. Memorizing is a skill that helps a student to remember the materials they have learned during the lecture process. Some studies have explained that before someone remembers something, memory usually works to manipulate the information first; however, shortterm memory assignments involves direct withdrawal without any opportunities to use or manipulate information (Davelaar, Goshen-Gottestein, Haarmann \& Usher, 2005; Brown, Neath, \& Chater, 2007; Diamond, 2017). Therefore, to store an information to long-term memory needs various supporting methods or techniques.

The number of students who has low writing skill is 22 people (50\%). Writing is a complex skill that needs good cognitive, metacognitive, emotional processes to produce useful and meaningful writing to support education process (Graham, Harris, \& McKeown, 2013; Boscolo \& Hidi, 2007). Writing is one of the skills needed to be mastered in order to adapt in the learning process in the university (Mateos, Villalon, de Dios, \& Martin, 2007). Assignments in the university include many writing projects, such as paper writing, lecture material resumes, presentations, articles, and scientific papers or final assignments.

Those learning skills are related to one another. Some skills such as language, vocabulary, memory work, inference, and integration skills are very important to give meaning while reading (Cain, Oakhill, \& Bryant, 2004; Ricketts, Bishop, \& Nation, 2007). Using or collaborating all learning skills optimally will give a satisfactory result (Gettinger \& Seibert, 2002). Improving learning skills will also improve students' learning results. One study shows that learning style and learning skills relate positively to students' learning results (Zahri, Yusuf, \& Neviyarni, 2017).

Various alternative interventions can be done to improve students' learning skills. One of them is by improving students' Emotion Regular Skill (ERS), which is an online focused emotion training method that aims to improve students' learning skills (Eckert, Ebert, Lehr, Sienland, \& Berking, 2016). Behavior cognitive approach in group form can also improve students' learning skills in doing the assignment (Rozental, Forsström, Nilsson, Rizzo, \& Carlbring, 2014).

Other interventions can also be given, such as giving some knowledge and understanding about the importance of improving learning skills and training students on the learning skills that contribute to the students' success in 
college (Walker, Mathew, \& Black, 2004; Newell-Jones, Osborne \& Masey, 2005; Hultberg, Plos, Hendry \& Kjellgren, 2008; Fergy, Heatley, Morgan \& Hodgson, 2008; Eifait \& Turley, 2009; Jansen \& Suhre, 2010).

Universities usually facilitate their students with various services and supporting activities, such as counseling and guidance services, training and seminars related to learning skills (Wernerbach, Crowley, Bates \& Rosenthal, 2014). However, students sometimes do not use the facilities to its maximum potential.

\section{References}

Artelt, C., \& Dörfler, T. (2010). Förderung der Lesekompetenz als Aufgabe aller Fächer. Forschungsergebnisse und Anregungen für die Praxis [Fostering reading literacy is a mission of a school subjects. Research results and practical implications]. In Bayerisches Staatsministerium für unterricht und Kultus (Ed.), ProLesen. Auf dem Weg zur Leseschule-Leseförderung in den gesellschaftswissenschaftlichen Fächern [Promoting reading in schools. Fostering reading comprehension in social science subjects] (pp. 13-36). Donauwörth, Germany: Auer.

Beaubouef, T., \& Mason, J. (2005). Why the high attrition rate for computer science students: Some thoughts and observations. ACM SIGCSE Bulletin, 37(2), 103-106.

Bodie, G. D. (2013). Issues in the measurement of listening. Communication Research Reports, 30(1), 76-84.

Bodie, G. D., Worthington, D., Imhof, M., \& Cooper, L. O. (2008). What would a unified field of listening look like? A proposal linking past perspectives and future endeavors. International Journal of Listening, 22(2), 103-122.

Boscolo, P., \& Hidi, S. (2007). The multiple meanings of motivation to write. In: P. Boscolo, \& S. Hidi (Eds.), Studies in writing (pp. 1-14). Oxford, UK: Elsevier.

Breznitz, Z., Shaul, S., Horowitz-Kraus, T., Sela, I., Nevat, M., \& Karni, A. (2013). Enhanced reading by training with imposed time constraint in typical and dyslexic adults. Nature Communications, 4.

Brown, G. D. A., Neath, I., \& Chater, N. (2007). A ratio model of scale-invariant memory and identification. Psychological Review, 114(3), 539-576.

Cain, K., Oakhill, J., \& Bryant, P. (2004). Children's reading comprehension ability: Concurrent prediction by working memory, verbal ability and component skills. Journal of Educational Psychology, 96(1), 31-42.

Conley, D. T. (2005). College Knowledge: What It Really Takes for Students to Succeed and What We Can Do to Get Them Ready. San Fransisco: Jossey-Bass.

Davelaar, E. J., Goshen-Gottstein, Y. A. A., Haarmann, H. J., \& Usher, M. (2005). The demise of short-term memory revisited: Empirical and computational investigation of recency effects. Psychological Review, 112(1), 3-42.

Davis, D. F. (2001). Two ears and one mouth: Two eyes and one hand. Listening Post, 77, 10-13.

Diamond, A. (2013). Executive functions. Annual Review of Psychology, 64, 135-168.

Eckert, M., Ebert, D. D., Lehr, D., Sieland, B., \& Berking, M. (2016). Overcome procrastination : Enhancing emotion regulation skills reduce procrastination. Journal Learning and Individual Differences, 52, 10-18.

Einfait, J., \& Turley, J. (2009). Engaging First Year Students in Skill Development: A Threeway Collaborative Model in Action". Journal of Academic Language and Learning, 3(2), 105-16.

Elliot, S. N., Kratochwill, T. R., Cook J. L. \& Travers J. F. (2000). Educational Psychology: Effective Teaching, Effective Learning. Dubuque: Brown \& Benchmark.

Fergy, S., Heatley, S., Morgan, G. \& Hodgson, D. (2008). The impact of pre-entry study skills training programmes on students first year experience in health and social care programmes. Journal Nurse Education in Practice, $8(1), 20-30$.

Ferrari-Bridgers, F., Vogel, R., \& Lynch, B. (2015). Fostering and assessing critical listening skills in the speech course. International Journal of Listening, 1-14.

Fitri, E., Ifdil, I., \& Neviyarni, N. (2016). Efektivitas layanan informasi dengan menggunakan metode blended learning untuk meningkatkan motivasi belajar. Jurnal Psikologi Pendidikan \& Konseling, 2(2), 84-92.

Flynn, J., Välikoski, T.-R., \& Grau, J. (2008). Listening in the business context: Reviewing the state of research. International Journal of Listening, 22(2), 141-151.

Gettinger, M., \& Seibert, J. K. (2002). Contributions of study skills to academic competence. Journal School Psychology, 31(3), 350-365.

Gourlay, L. (2009). Threshold practices: Becoming a student through academic literacies. Journal Education, 7(2), $181-192$. 
Graham, S., Harris, K. R., \& McKeown, D. (2013). The writing of students with LD and a metaanalysis of SRSD writing intervention studies: Redux. In: L. Swanson, K. R. Harris, \& S. Graham (Eds.), Handbook of learning disabilities (2d ed., pp. 405-438). New York, NY: Guilford.

Grills, S. (2017). Learning skills workshops supporting first-year courses. Journal Collected Essays on Learning and Teaching, 10, 119-128.

Hiester, M., Nordstrom, A., \& Swenson, L. M. (2009). Stability and change in parental attachment and adjustment outcomes during the first semester transition to college life. Journal of College Student Development, 50(5), $521-538$.

Horowitz-Kraus, T., Cicchino, N., Amiel, M., Holland, S. K., \& Breznitz, Z. (2014). Reading improvement in Englishand Hebrew-speaking children with reading difficulties after reading acceleration training. Annals of Dyslexia, 64(3), 183-201.

Hultberg, J., Plos, K., Hendry, G. D. \& Kjellgren, K. I. (2008). Scaffolding students transition to higher education: Parallel introductory courses for students and teachers. Journal of Further and Higher Education, 23(1), 4757.

Hussain, I., \& Sultan, S. (2010). Analysis of procrastination among university students. Procedia Social and Behavioral Sciences, 5(2), 1897-1904.

Isari, V., Efendi, Z. M., \& Neviyarni, N. (2017). Perbedaan latar belakang pendidikan dan masa kerja guru bimbingan dan konseling terhadap pelaksanaan layanan bimbingan dan konseling format klasikal. Jurnal Bikotetik, 1(1), 21-29.

Jansen, E. P. W. A. \& Suhre, C. J. M. (2010). The effect of secondary school study skills preparation on first-year university achievement. Journal Educational Studies, 36(5), 569-580.

Janusik, L. A. (2007). Building listening theory: The validation of the conversational listening span. Communication Studies, 58(2), 139-156.

Kagan, M., Çak, O., Ilhan, T., \& Kandemir, M. (2010). The explanation of the academic procrastination behaviour of university students with perfectionism, obsessive- compulsive and five factor personality traits. Procedia Social And Behavioral Sciences, 2(2), 2121-2125.

Kiamarsi, A., \& Abolghasemi, A. (2014). The relationship of procrastination and self-efficacy with psychological vulnerability in students. Procedia - Social And Behavioral Sciences, 114, 858-862.

Kreniske, P. (2017). How first-year students expressed their transition to college experiences differently depending on the affordances of two writing contexts. Computers and Composition, 45, 1-20.

Leppanen, U., Aunola, K., \& Nurmi, J.-E. (2005). Beginning readers' reading performance and reading habits. Journal of Research in Reading, 28(4), 383-399.

Mateos, M., Villalon, R., de Dios, M. J., \& Martin, E. (2007). Reading and writing tasks on different university degree courses: What do the students say they do? Studies in Higher Education, 32(4), 489-510.

McGeown, S. P., Duncan, L. G., Griffiths, Y. M., \& Stothard, S. E. (2014). Exploring the relationship between adolescent's reading skills, reading motivation and reading habits. Journal Reading and Writing, 28(4), 545569.

Nevo, E., Brande, S., \& Shaul, S. (2015). The effects of two different reading acceleration training programs on improving reading skills of second graders. Reading Psychology, 37(4), 1-14.

Newell-Jones, K., Osborne, D. \& Massey, D. (2005). Academic skills development changing attitudes through a community of practice. Journal of Learning and Teaching, 2(1), 1-9.

Pan, D. (2004). The effective student, a guide to learning for the nus student. Singapore: Continental Press Pte Ltd.

Pepe, K. (2012). A research ofthe relationship between study skills of students and their GPA. Procedia Social and Behavioral Sciences, 47, 1048-1057.

Pfost, M., Hattie, J., Dörfler, T., \& Artelt, C. (2014). Individual differences in reading development: A review of 25 years of empirical research on matthew effects in reading. Review Of Educational Research, 84(2), 203-244.

Ricketts, J., Nation, K., \& Bishop, D. V. M. (2007). Vocabulary is important for some, but not all reading skills. Scientific Studies of Reading, 11(3), 235-257.

Rozental, A., Forsström, D., Nilsson, S., Rizzo, A., \& Carlbring, P. (2014). Group versus internet-based cognitivebehavioral therapy for procrastination: Study protocol for a randomized controlled trial . Journal INVENT, $1(2), 84-89$.

Smith, C. B. (2000). Reading to learn: How to study as you read. Bloomington: ERIC Clearinghouse on Reading, English and Communication. Indiana University.

Snowling, M. J. (2001). From language to reading and dyslexia. Dyslexia, 7(1), 37-46.

Sumintono, B., \& Widhiarso, W. (2014). Aplikasi model rasch untuk penelitian ilmu-ilmu sosial. Bandung: TrimKom Publishing House. 
Sukmawati, I., Neviyarni, N., Syukur, Y., \& Said, A. (2013). Peningkatan hasil belajar melalui dinamika kelompok dalam perkuliahan Pengajaran Psikologi dan Bimbingan Konseling (PPBK). Jurnal Ilmiah Ilmu Pendidikan, 13(2), 10-18.

Tanjung, R. F., Neviyarni, N., \& Firman, F. 2017. Instrumen keterampilan belajar RNF. Padang: Universitas Negeri Padang.

Thomas, C. R., \& Gadbois, S. A. (2007). Academic self-handicapping: The role of self-concept clarity and students learning strategies. Journal of Educational Psychology, 77(1), 101-119.

Thompson, K., Leintz, P., Nevers, B., \& Witkowski, S. (2004). The integrative listening model: An approach to teaching and learning listening. The Journal of General Education, 53(3-4), 225-246.

Walker, L., Matthew, B \& Black, F. (2004). Widening access and student non-completion: an inevitable link? Evaluating the effects of the top-up programme on student completion. International Journal of Lifelong Education, 23(1), 43-59.

Wernersbach, B. M., Crowley, S. L., Bates, S. C., \& Rosenthal, C. (2014). Study skills course impact on academic self-efficacy. Journal of Developmental Education, 37(3), 14-33.

Wolvin, A. D. (2012). Listening in the general education curriculum. The International Journal of Listening, 26(2), $122-128$.

Vellutino, F. R., Fletcher, J. M., Snowling, M. J., \& Scanlon, D. M. (2004). Specific reading disability (dyslexia): What have we learned in the past four decades? Journal of Child Psychology and Psychiatry, 45(1), 2-40.

Zahri, T. N., Yusuf, A. M., \& Neviyarni, N. (2017). Hubungan gaya belajar dan keterampilan belajar dengan hasil belajar mahasiswa. Konselor, 6(1), 18-23. 